\title{
HUBUNGAN MOTIVASI DAN KOMITMEN ORGANISASI DENGAN KINERJA PERAWAT DALAM PELAKSANAAN DOKUMENTASI ASUHAN KEPERAWATAN
}

\author{
Nur Miladiyah $\mathrm{R}^{1,2^{*}}$, Mustikasari ${ }^{3}$, Dewi Gayatri ${ }^{3}$ \\ 1. STIKes Bani Saleh, Bekasi 17113 Indonesia
}

2. Program Studi Magister, Fakultas Ilmu Keperawatan, Universitas Indonesia, Depok 16424, Indonesia

3. Fakultas Ilmu Keperawatan, Universitas Indonesia, Depok 16424, Indonesia

*E-mail: nurmiladiyahr@yahoo.co.id

\begin{abstract}
Abstrak
Motivasi dan komitmen organisasi merupakan faktor yang meningkatkan dan membangun kinerja perawat secara konstruktif dalam menghasilkan kualitas asuhan keperawatan yang bermutu. Penelitian ini bertujuan untuk mengetahui hubungan motivasi dan komitmen organisasi dengan kinerja perawat dalam pelaksanaan dokumentasi asuhan keperawatan di sebuah Rumah Sakit di Bekasi. Jenis penelitian ini adalah deskriptif korelasi dengan rancangan cross sectional. Sampel penelitian ini adalah seratus enam perawat pelaksana dengan menggunakan kuesioner dan observasi dokumentasi asuhan keperawatan. Analisis dengan univariat, bivariat (chi square), dan multivariat (regresi logistik berganda). Hasil penelitian menunjukkan bahwa ada hubungan antara motivasi dan kinerja perawat dalam pelaksanaan dokumentasi asuhan keperawatan $(p=0,000 ; \alpha=0,05)$. Motivasi ekstrinsik memengaruhi kinerja perawat dua puluh enam kali lebih tinggi $(\mathrm{OR}=26,708)$ setelah dikontrol oleh variabel umur, status kepegawaian, dan masa kerja. Perlu dilakukan audit dokumentasi sebagai bagian dari penilaian kinerja perawat.
\end{abstract}

Kata kunci: dokumentasi asuhan keperawatan, kinerja komitmen organisasi motivasi

\section{Abstract}

Motivation and Organizational Commitment Determine Nursing Quality and Performance in ones Hospital Bekasi. Motivation and organizational commitment is a factor that can increase positive attitudes towards work and build constructively nurses performance in producing quality nursing care quality. Study is to examine the relationship between motivation and commitment to the organization's performance in implementing nursing documentation of nursing care in hospitals Bekasi. This descriptivestudy with cross sectional correlation. Sample of 106 nurses using questionnaires and observation documentation of nursing care with univariate analysis, bivariate (chi-square) and multivariate (multiple logistic regression). The research results concluded there was relationship between motivation with nurses' performance in implementing nursing care documentation $(p=0,000 ; \alpha=0,05)$. Extrinsic motivation could affect the performance of nurses 26 times higher $(O R=26,708)$ after controlled by age, employment status, and years of service. Audit documentation needs to be done as part of the performance assessment nurse.

Keywords: documentation of nursing, motivation, organizational commitment, performance

\section{Pendahuluan}

Rumah sakit sebagai salah satu sarana kesehatan dituntut untuk dapat memberikan pelayanan yang bermutu sesuai standar yang sudah ditentukan dalam meningkatkan derajat kesehatan masyarakat. Perawat sebagai profesi yang mandiri dituntut untuk dapat memberikan kualitas asuhan keperawatan yang berkualitas kepada individu, keluarga, dan masyarakat (Delaune, 2002). Perawat sebagai tenaga profesional dituntut untuk mampu menunjukkan kinerja yang sesuai dengan standar yang telah ditetapkan.

Kinerja adalah suatu pekerjaan yang dilakukan berdasarkan pada proses suatu tindakan dan evaluasi hasil tindakan (Sonentag \& Frese, 2001). Motivasi yang relatif stabil membuat staf bekerja 
lebih baik dalam meningkatkan kinerja kerjanya (Robbins, 2006). Kanfer, Chen, dan Pritchard (2008) menyatakan bahwa motivasi kerja merupakan faktor yang meningkatkan kinerja secara konstruktif. Motivasi perawat berperan dalam menghasilkan kualitas asuhan keperawatan yang bermutu. Penelitian yang dilakukan Khan, et al., (2010) menyatakan bahwa salah satu determinan kinerja adalah komitmen organisasi. Hasil penelitian yang dilakukan Lee dan Olshfsi (2002) dalam Khan, et al., (2010) menyatakan bahwa komitmen organisasi tinggi menyebabkan karyawan menyukai dan menyelesaikan pekerjaannya dengan baik sehingga dapat meningkatkan kinerja.

Berdasarkan Joints Commission Internatioanl Accreditation (JCIA, 2011) asuhan keperawatan yang diberikan kepada setiap pasien harus terencana dan tertulis dalam dokumentasi asuhan keperawatan. Penilaian kinerja perawat pelaksana yang sudah berjalan di sebuah Rumah Sakit (RS) di Bekasi meliputi tiga komponen, yaitu kedisiplinan staf, produktivitas kerja, dan perilaku terhadap pekerjaannya. Produktivitas kerja perawat dinilai berdasarkan nilai ketercapaian terhadap standar asuhan keperawatan (SAK). Berdasarkan Departemen Kesehatan (Depkes, 2005), standar pelayanan dan standar asuhan keperawatan berfungsi sebagai alat ukur untuk mengetahui dan memantau pelayanan kualitas asuhan keperawatan yang dilakukan di rumah sakit sudah memenuhi persyaratan sesuai dengan standar. Kualitas pelayanan keperawatan salah satunya dapat diukur dari ketercapaian standar asuhan keperawatan. Menurut standar kinerja rumah sakit (Depkes Republik Indonesia, 2005) hasil persentase penilaian minimal ketercapaian standar asuhan keperawatan sebesar $85 \%$. Hasil audit dokumentasi penerapan SAK di sebuah RS di Bekasi pada tahun 2012 dari tiga belas ruangan yang menjadi sasaran evaluasi SAK, hanya lima ruangan yang telah memenuhi SAK (>85\%). Hasil audit menunjukkan bahwa hanya $38 \%$ ruangan rawat inap yang telah memenuhi standar ketercapaian SAK, 62\% ruangan yang lain belum memenuhi standar SAK $(<85 \%)$, sehingga rerata nilai ketercapaian SAK seluruh ruang rawat inap sebesar $64 \%$.
Kondisi ini mengalami penurunan sebesar $25 \%$ dari kondisi pada tahun 2011, yaitu pada tahun 2011 ketercapaian SAK mencapai 89\%.

Penurunan ketercapaian SAK disebabkan oleh kurangnya kesadaran perawat tentang pentingnya pendokumentasian asuhan keperawatan secara lengkap, pengisian identitas pasien yang kurang lengkap, rencana tindakan yang tidak sesuai dengan diagnosis keperawatan, sebagian tindakan terutama pada pergantian kerja sore dan malam, tidak sesuai dengan rencana yang telah dibuat, dan pada catatan perawatan sering tidak mencantumkan nama dan paraf perawat.

Komitmen perawat juga dipengaruhi oleh status kepegawaian dari staf karena $40 \%$ perawat pelaksana yang berada di sebuah RS di Bekasi merupakan tenaga kerja kontrak. Hal ini menyebabkan angka turn over di sebuah RS di Bekasi pada tahun 2012 adalah sebesar 1, 91\%. Kurangnya kedisiplinan staf dan status kepegawaian staf merupakan bagian dari permasalahan komitmen organisasi yang akan berdampak terhadap kinerja perawat.

Pentingnya motivasi dan komitmen perawat terhadap tujuan dan kebijakan organisasi adalah sebagai daya dorong dalam meningkatkan kinerja staf. Berdasarkan fenomena ini, peneliti menganggap penting untuk meneliti hubungan antara motivasi dan komitmen organisasi terhadap kinerja perawat dalam melaksanakan dokumentasi asuhan keperawatan di sebuah RS di Bekasi. Penelitian ini bertujuan untuk mengidentifikasi hubungan motivasi dan komitmen organisasi terhadap kinerja perawat dalam pelaksanaan dokumentasi asuhan keperawatan di sebuah RS di Bekasi.

\section{Metode}

Desain penelitian ini adalah deskriptif korelasi dengan rancangan cross sectional. Kuesioner diberikan kepada seratus enam orang perawat pelaksana di ruang rawat inap sebuah $\mathrm{RS}$ di Bekasi. Data dikumpulkan menggunakan kuesioner dan observasi dokumentasi asuhan keperawatan. Kuesioner meliputi karakteristik perawat, motivasi, 
dan komitmen organisasi. Lembar observasi penilaian kinerja perawat melalui berkas rekam medis pasien. Data dianalisis dengan univariat menggunakan tabel distribusi frekuensi, analisis bivariat menggunakan uji chi-square, dan analisis multivariat menggunakan uji regresi logistik.

\section{Hasil}

Karakteristik perawat meliputi umur, jenis kelamin, masa kerja, tingkat pendidikan, dan status kepegawaian perawat di ruang rawat inap sebuah RS di Bekasi. Berdasarkan Tabel 1 didapat bahwa karakteristik responden berumur 20-35 tahun $(76,4 \%)$, berjenis kelamin perempuan $(83,6 \%)$, masa kerja kurang dari10 tahun $(66 \%)$, pendidikan D-3 keperawatan $(84,9 \%)$ dan pegawai negeri sipil $(53,8 \%)$.

Berdasarkan Tabel 2 didapat bahwa motivasi perawat dipersepsikan masih kurang $(58,5 \%)$. Motivasi yang dirasakan masih kurang adalah motivasi instrinsik $(57,5 \%)$ dan motivasi ekstrinsik $(55,7 \%)$.

Tabel 1. Karak-teristik Responden

\begin{tabular}{lcc}
\hline \multicolumn{1}{c}{ Variabel } & Jumlah & $\begin{array}{c}\text { Persentase } \\
(\%)\end{array}$ \\
\hline Umur & & \\
a. 20-35 tahun & 81 & 76,4 \\
b. 36-55 tahun & 25 & 23,6 \\
Jenis Kelamin & & \\
a. Pria & 18 & 17 \\
b. Wanita & 88 & 83 \\
Masa Kerja & & \\
a. <10 tahun & 70 & 66 \\
b. >10 tahun & 36 & 34 \\
$\begin{array}{l}\text { Pendidikan terakhir } \\
\text { a. Surat Perintah Kerja }\end{array}$ & 10 & \\
$\quad$ (SPK) & 90 & 84,4 \\
b. D-3 Keperawatan, & 6 & 5,7 \\
c. S-1 Keperawatan+ & & \\
$\quad$ Ners & & \\
Status Kepegawaian & & \\
a. Pegawai Negeri Sipil & 57 & 53,8 \\
$\quad$ (PNS) & 49 & 46,2 \\
b. Tenaga Kerja kontrak & & \\
$\quad$ (TKK) & & \\
\hline
\end{tabular}

Berdasarkan Tabel 3 terlihat bahwa responden yang memiliki komitmen kurang mempunyai selisih $6 \%$ lebih besar daripada responden yang memiliki komitmen baik. Responden mempunyai komitmen afektif yang baik $(90,6 \%)$, komitmen normatif yang baik $(96,2 \%)$, dan komitmen continuance baik $(82,1 \%)$.

Tabel 2. Motivasi Perawat Pelaksana

\begin{tabular}{lcc}
\hline Variabel & Jumlah & Persentase \\
\hline Motivasi & & \\
a. Baik & 44 & 41,5 \\
b. Kurang & 62 & 58,5 \\
Motivasi Instrinsik & & \\
a. Baik & 45 & 42,5 \\
b. Kurang & 61 & 57,5 \\
Motivasi Ekstrinsik & & \\
a. Baik & 47 & 44,3 \\
b. Kurang & 59 & 55,7 \\
\hline
\end{tabular}

Tabel 3. Komitmen Organi-sasi Perawat Pelaksana

\begin{tabular}{ccc}
\hline \multicolumn{1}{c}{ Variabel } & Jumlah & Persentase \\
\hline Komitmen Organisasi & & \\
a. Baik & 51 & 48 \\
b. Kurang & 55 & 52 \\
Komitmen Afektif & & \\
a. Baik & 96 & 90,6 \\
b. Kurang & 10 & 9,4 \\
Komitmen Normatif & & \\
a. Baik & 102 & 96,2 \\
b. Kurang & 4 & 3,8 \\
Komitmen Continuance & & \\
a. Baik & 87 & 82,1 \\
b. Kurang & 19 & 17,9 \\
\hline
\end{tabular}

Tabel 4. Kinerja Perawat dalam Pelaksanaan Dokumentasi Asuhan Keperawatan

\begin{tabular}{lcc}
\hline Variabel & Jumlah & Persentase \\
\hline Kinerja Pelaksanaan & & \\
Dokumentasi Asuhan & & \\
Keperawatan & & \\
a. Baik & 54 & 51 \\
b. Kurang & 52 & 49 \\
\hline
\end{tabular}

Hasil kinerja perawat diukur berdasarkan nilai rerata dari tiga berkas rekam medis pasien 
pulang. Berdasarkan Tabel 4 terlihat bahwa kinerja perawat pelaksana yang mempunyai kinerja baik dalam pelaksanaan dokumentasi asuhan keperawatan berdasarkan rekam medis sebanyak lima puluh empat orang (51\%).

Berdasarkan pada Tabel 5 dapat dijelaskan bahwa proporsi perawat yang mempunyai motivasi baik dan menunjukkan kinerja yang baik dalam pelaksanaan dokumentasi asuhan keperawatan adalah sebesar $72,7 \%$. Perawat yang memiliki motivasi yang kurang dan menunjukkan kinerja yang baik adalah sebesar 48,9\%. Hasil uji statistik terdapat hubungan antara motivasi dan kinerja perawat dalam pelaksanaan dokumentasi asuhan keperawatan $(p=0,000 ; \alpha=0,05)$.

Hasil akhir dari analisis multivariat menunjukkan bahwa komponen motivasi yang paling berhubungan dengan kinerja perawat dalam pendokumentasian asuhan keperawatan adalah motivasi ekstrinsik dapat mempengaruhi kinerja perawat dua puluh enam kali lebih tinggi $(\mathrm{OR}=26,708)$ setelah dikontrol oleh variabel umur, status kepegawaian, dan masa kerja.

Tabel 5. Hubungan antara Motivasi dan Kinerja Perawat dalam Pelaksanaan Dokumentasi Asuhan Keperawatan

\begin{tabular}{|c|c|c|c|c|c|c|c|c|c|}
\hline \multirow{3}{*}{ Variabel } & \multicolumn{4}{|c|}{ Kinerja Dokumentasi } & \multirow{2}{*}{\multicolumn{2}{|c|}{ Total }} & \multirow{3}{*}{$X^{2}$} & \multirow{3}{*}{$\mathbf{P}$} & \multirow{3}{*}{$\begin{array}{c}\text { OR } \\
(95 \% \mathrm{CI})\end{array}$} \\
\hline & \multicolumn{2}{|c|}{ Kurang } & \multicolumn{2}{|c|}{ Baik } & & & & & \\
\hline & $\mathbf{N}$ & $\%$ & $\mathbf{N}$ & $\%$ & $\mathbf{N}$ & $\%$ & & & \\
\hline \multicolumn{10}{|l|}{ Motivasi } \\
\hline a. Kurang & 41 & 66,1 & 21 & 33,9 & 44 & 100 & 14,027 & $0,000^{*}$ & 5,206 \\
\hline b. Baik & 12 & 27,3 & 32 & 72,7 & 62 & 100 & & & $(2,233 ; 12,140)$ \\
\hline \multicolumn{10}{|l|}{ Motivasi Instrinsik } \\
\hline a. Kurang & 30 & 49,2 & 31 & 46,7 & 61 & 100 & 0,000 & 3 & 0,926 \\
\hline b. Baik & 23 & 51,1 & 22 & 48,9 & 45 & 100 & & 1,000 & $(0,428 ; 2,000)$ \\
\hline \multicolumn{10}{|l|}{ Motivasi Ekstrinsik } \\
\hline a. Kurang & 46 & 78 & 13 & 13 & 47 & 100 & 39,143 & 0,000 & 5.235 \\
\hline b. Baik & 7 & 14,9 & 40 & 85,1 & 59 & 100 & & $*$ & $(2,608 ; 10,507)$ \\
\hline
\end{tabular}

Tabel 6. Hubungan antara Komitmen Organisasi dan Kinerja Perawat dalam Pelaksanaan Dokumentasi Asuhan Keperawatan

\begin{tabular}{|c|c|c|c|c|c|c|c|c|c|}
\hline \multirow{3}{*}{ Variabel } & \multicolumn{4}{|c|}{ Kinerja Dokumentasi } & \multirow{2}{*}{\multicolumn{2}{|c|}{ Total }} & \multirow{3}{*}{$X^{2}$} & \multirow{3}{*}{$P$} & \multirow{3}{*}{$\begin{array}{c}\text { OR } \\
(95 \% \mathrm{CI})\end{array}$} \\
\hline & \multicolumn{2}{|c|}{ Kurang } & \multicolumn{2}{|c|}{ Baik } & & & & & \\
\hline & $\mathbf{N}$ & $\%$ & $\mathbf{N}$ & $\%$ & $\mathbf{n}$ & $\%$ & & & \\
\hline $\begin{array}{l}\text { Komitmen organisasi } \\
\text { a. Kurang } \\
\text { b. Baik }\end{array}$ & $\begin{array}{l}27 \\
27\end{array}$ & $\begin{array}{l}49 \\
53\end{array}$ & $\begin{array}{l}28 \\
24\end{array}$ & $\begin{array}{l}51 \\
47\end{array}$ & $\begin{array}{l}55 \\
51\end{array}$ & $\begin{array}{l}100 \\
100\end{array}$ & 0,023 & 0,692 & $\begin{array}{c}0,857 \\
(0,400: 0,838)\end{array}$ \\
\hline $\begin{array}{l}\text { Komitmen afektif } \\
\text { a. Kurang } \\
\text { b. Baik }\end{array}$ & $\begin{array}{l}4 \\
50\end{array}$ & $\begin{array}{l}40 \\
52,1\end{array}$ & $\begin{array}{l}6 \\
46\end{array}$ & $\begin{array}{l}60 \\
47.9\end{array}$ & $\begin{array}{l}10 \\
96\end{array}$ & $\begin{array}{l}100 \\
100\end{array}$ & 0,156 & 0,693 & $\begin{array}{c}0,613 \\
(0,163 ; 2,31)\end{array}$ \\
\hline $\begin{array}{l}\text { Komitmen Normatif } \\
\text { a. Kurang } \\
\text { b. Baik }\end{array}$ & $\begin{array}{l}1 \\
53\end{array}$ & $\begin{array}{l}25 \\
52\end{array}$ & $\begin{array}{l}3 \\
49\end{array}$ & $\begin{array}{l}75 \\
48\end{array}$ & $\begin{array}{l}4 \\
102\end{array}$ & $\begin{array}{l}100 \\
100\end{array}$ & 0,301 & 0,584 & $\begin{array}{c}0,308 \\
(0,031 ; 3,06)\end{array}$ \\
\hline $\begin{array}{l}\text { Komitmen Continuance } \\
\text { a. Kurang } \\
\text { b. Baik }\end{array}$ & $\begin{array}{l}9 \\
45\end{array}$ & $\begin{array}{l}47,7 \\
51,7\end{array}$ & $\begin{array}{l}10 \\
42\end{array}$ & $\begin{array}{l}52,6 \\
48,3\end{array}$ & $\begin{array}{l}9 \\
87\end{array}$ & $\begin{array}{l}100 \\
100\end{array}$ & 0,008 & 0,928 & $\begin{array}{c}0,840 \\
(0,311 ; 2,26)\end{array}$ \\
\hline
\end{tabular}




\section{Pembahasan}

Berdasarkan hasil pengukuran berkas rekam medis pasien didapatkan hasil kinerja perawat dalam pelaksanaan dokumentasi asuhan keperawatan sebesar $51 \%$ responden mempunyai kinerja yang baik dalam pelaksanaan dokumentasi asuhan keperawatan. Menurut Jefferies, et al., (2011), proporsi perawat yang melakukan dokumentasi asuhan keperawatan dengan baik harus meliputi komponen-komponen pengkajian, diagnosis, perencanaan, implementasi, dan evaluasi. Kelima komponen tersebut harus didokumentasikan secara jelas dan berurutan, sehingga dapat dipahami oleh semua profesi.

Pengukuran kinerja merupakan serangkaian kegiatan perawat yang memiliki kompetensi pengetahuan, keterampilan, dan pengambilan keputusan klinis. Kualitas dokumentasi asuhan keperawatan dipengaruhi oleh tingkat pengetahuan perawat dalam melakukan pendokumentasian dengan tata bahasa yang baik (Jefferies, et al., 2011). Menurut Wang (2011), penggunaan bahasa dan istilah yang tidak dimengerti dapat mengakibatkan berbagai interpretasi yang salah terhadap dokumentasi asuhan keperawatan.

Berdasarkan hasil analisis bivariat karakteristik responden ditemukan tidak ada hubungan antara karakteristik perawat pelaksana dan pelaksanaan dokumentasi asuhan keperawatan. Hal ini disebabkan oleh semua perawat mempunyai kewajiban yang sama dalam mendokumentasikan asuhan keperawatan yang telah dilakukan terhadap kliennya karena dokumentasi asuhan keperawatan merupakan salah satu aspek legal sebagai bentuk pertanggungjawaban perawat terhadap pasien, tanpa dipengaruhi oleh karakteristik responden (Owen, 2005).

Hasil penelitian menunjukkan bahwa terdapat hubungan antara motivasi dan kinerja perawat dalam pelaksanaan dokumentasi asuhan keperawatan ( $p=0,000 ; \alpha=0,05)$. Hasil penelitian ini sejalan dengan penelitian yang dilakukan oleh Indrastuti, Hamid, dan Mustikasari (2010). Kanfer, Chen, dan Pritchard (2008) menyatakan bahwa motivasi kerja merupakan faktor yang dapat meningkatkan kinerja secara konstruktif. Hasil analisis subvariabel terdapat hubungan yang signifikan antara motivasi ekstrinsik dan kinerja perawat dalam pelaksanaan dokumentasi asuhan keperawatan $(p=0,000 ; \alpha=0,05)$. Hasilnya menunjukkan bahwa perawat yang mempunyai motivasi ekstrinsik baik berpeluang menunjukkan kinerja baik lima kali lebih besar dibandingkan dengan perawat yang mempunyai motivasi kurang $(\mathrm{OR}=$ $5,235)$.

Menurut Herzberg, et al., (1959) dalam Lu (2000), motivasi kerja individu dapat ditelaah secara instrinsik maupun ekstrinsik. Menurut Lu (2000), seseorang yang mempunyai motivasi ekstrinsik kuat dipengaruhi oleh insentif dan kondisi kerja, seperti lingkungan pekerjaan, hubungan antarstaf, dan kebijakan yang dikeluarkan oleh perusahaan. Motivasi berdasarkan pada bagaimana seseorang mengevaluasi kompetensi sesuai dengan tujuan awal tindakan dan apakah kompetensi tersebut sudah sesuai dengan pencapaian yang diharapkan (Nicholls, 1984 dalam Domangue \& Solmon, 2010).

Berdasarkan hasil pengamatan peneliti, salah satu faktor motivasi ekstrinsik yang dapat meningkatkan kinerja adalah supervisi pimpinan. Tingginya supervisi kepala ruangan terhadap kinerja perawat dalam pelaksanaan dokumentasi menghasilkan kualitas dokumentasi asuhan keperawatan yang baik. Ada tiga ruangan $(37,5 \%)$ yang memiliki kinerja dokumentasi asuhan keperawatan yang baik $(>85 \%)$ karena mendapatkan supervisi dari kepala ruangan secara optimal. Kepala ruangan memberikan bimbingan proses dokumentasi asuhan keperawatan dan umpan balik terhadap hasil asuhan keperawatan yang telah didokumentasikan.

Peningkatan mdffiasidi ug̈kstritisitkk dapalu rofjuldkarkbahwa peraw dengan memperhatikan kesejahteraan staf. Berdasarkan analisis instrumen, perawat merasa adanya penghargaan yang disesuaikan dengan beban kerja dan kinerja membuat mereka lebih termotivasi dalam meningkatkan kinerjanya. Hal ini menunjukkan bahwa kebutuhan perawat terhadap hadiah yang berupa promosi atau peningkatan pendidikan juga sangat tinggi, yang dibutuhkan 
oleh staf adalah program-program pelatihan atau pendidikan berkelanjutan untuk meningkatkan kompetensi perawat.

Komponen berikutnya yang terdapat dalam subvariabel motivasi ekstrinsik adalah hubungan antarstaf. Berdasarkan analisis kuesioner, mayoritas perawat menyatakan hubungan antarstaf yang baik. Berdasarkan Robbins (2006), kebutuhan untuk berhubungan antarstaf merupakan kebutuhan seseorang untuk dapat berafiliasi dengan orang lain. Marquis dan Huston (2010) menyatakan bahwa hubungan antarstaf yang harmonis memudahkan seseorang untuk berinteraksi dengan orang lain, membantu pencapaian target kinerja individu.

Berdasarkan hasil penelitian, responden yang memiliki komitmen organisasi yang kurang sekitar 52\%. Hal ini sejalan dengan hasil penelitian yang dilakukan oleh Rose dan Kumar (2009), Yatnikasari, et al., (2010). Hasil ini menunjukkan bahwa responden yang memiliki komitmen kerja kurang lebih besar daripada responden yang memiliki komitmen kerja baik. Hasil uji statistik, tidak ditemukan subvariabel komitmen organisasi yang berhubungan dengan kinerja perawat dalam pendokumentasian asuhan keperawatan. Hasil ini sejalan dengan penelitian McMurray, et al., (2004) yang menyatakan bahwa ada faktor lain yang menyebabkan tidak adanya hubungan antara komitmen organisasi dan kinerja staf. McMurray, et al., (2004) menyatakan bahwa iklim organisasi secara tidak langsung dapat memengaruhi hasil kinerja. Komponen dari iklim organisasi yang dapat meningkatkan komitmen staf adalah adanya hubungan antarstaf yang baik, lingkungan kerja yang kondusif sehingga terdapat keterlibatan staf dalam kegiatan-kegiatan yang dilakukan organisasi.

Hasil analisis menunjukkan bahwa subvariabel komitmen afektif menunjukan proporsi perawat yang mempunyai komitmen afektif tinggi dan mempunyai kinerja pendokumentasian asuhan keperawatan yang kurang disebabkan oleh sebagian besar responden mempunyai masa kerja yang kurang dari sepuluh tahun. Menurut Meyer, Stanley, Herscovitch, dan Topolnytsky
(2001), komitmen afektif merupakan komponen emosional dari staf dalam mengidentifikasi dan terlibat dalam pencapaian tujuan organisasi sehingga dengan masa kerja yang singkat keterikatan secara emosional belum terbentuk.

Hasil penelitian menunjukkan bahwa responden yang mempunyai komitmen normatif baik dan menunjukkan kinerja baik sebesar (49\%). Menurut Meyer, et al., (2001) komitmen normatif merupakan perasaan staf untuk tetap berkewajiban secara moral tetap dalam organisasi untuk sejumlah alasan. Tingginya proporsi perawat yang mem-punyai komitmen normatif yang baik, salah satunya disebabkan oleh status kepegawaian responden. Sebagian besar responden $(53,8 \%)$ berstatus sebagai pegawai negeri sipil (PNS). Sebagai PNS, mereka akan menerima dan mengadopsi kebijakan yang terdapat dalam organisasi karena kebijakan yang dikeluarkan melalui surat keputusan dan juga disahkan oleh pemerintah. Keadaan ini menyebabkan perawat sebagai PNS mempunyai rasa keterikatan yang besar terhadap organisasi dan mengikuti semua kebijakan yang sudah ditetapkan oleh organisasi.

Menurut Meyer, et al., (2001), staf dengan komitmen continuance yang tinggi akan tetap berada dalam organisasi untuk menghindari biaya yang harus dikeluarkan bila mereka meninggalkan organisasi. Berdasarkan analisis kuesioner, $87 \%$ responden merasakan terdapat keseimbangan antara gaji dan tanggung jawab yang dilakukan, mendapatkan kenaikan gaji berkala sesuai dengan kinerja yang telah dilakukan, dan responden merasa akan rugi secara moril dan materiil bila keluar dari rumah sakit. Menurut McMurray, et al., (2004), komitmen organisasi dan kepercayaan staf yang tinggi terhadap organisasi secara signifikan merupakan salah satu determinan dalam pencapaian kinerja secara optimal. Berdasarkan analisis peneliti, perawat mendapatkan insentif dari jasa tindakan keperawatan, uang dinas malam, dan lain-lain sehingga mengakibatkan dampak yang positif terhadap komitmen continuance perawat terhadap rumah sakit. 


\section{Kesimpulan}

Berdasarkan hasil penelitian didapat karakteristik responden yang terdapat di sebuah RS di Bekasi sebagian besar berada pada umur 20-35 tahunan dengan masa kerja kurang dari sepuluh tahun, mempunyai latar belakang pendidikan D-3 keperawatan, dan berstatus sebagai pegawai negeri sipil. Hasil uji statistik menunjukkan bahwa ada hubungan antara motivasi dan kinerja perawat dalam pelaksanaan dokumentasi asuhan keperawatan. Hasil analisis-subvariabel motivasi didapatkan bahwa ada hubungan antara motivasi ekstrinsik dan kinerja perawat dalam pelaksanaan dokumentasi asuhan keperawatan. Hasil akhir analisis multivariat menunjukkan bahwa motivasi ekstrinsik dapat memengaruhi kinerja perawat dua puluh enam kali lebih tinggi setelah dikontrol oleh variabel umur, status kepegawaian, dan masa kerja. Namun, untuk faktor komitmen organisasi tidak ada hubungan antara komitmen organisasi dan kinerja perawat dalam pelaksanaan dokumentasi asuhan keperawatan. Hasil penelitian menunjukkan bahwa motivasi ekstrinsik memberikan kontribusi besar dalam meningkatkan kinerja perawat dalam pelaksanaan dokumentasi asuhan keperawatan di sebuah RS di Bekasi.

Penulis menyarankan agar RS dapat membuat kebijakan dengan menjadikan audit dokumentasi keperawatan sebagai salah satu indikator kinerja perawat. Perencanaan pengembangan sumber daya keperawatan dengan mengadakan program pendidikan berkelanjutan untuk perawat pelaksana yang masih berpendidikan D-3 keperawatan serta mengikutsertakan perawat dalam programprogram pelatihan yang dapat meningkatkan kemampuan dan kompetensi perawat pelaksana dalam melakukan asuhan keperawatan. Rumah sakit harus dapat menciptakan lingkungan dan kondisi kerja yang aman dan nyaman sebagai bagian dari motivasi ekstrinsik untuk lebih dapat meningkatkan kinerja perawat dengan penyediaan sarana dan prasarana penunjang tindakan keperawatan yang memadai serta mendukung dalam melaksanakan asuhan keperawatan (HH, EF, AR).

\section{Referensi}

Delaune, S.C. (2002). Fundamental of nursing: Standartdan practice (2nd Ed.). Sydney: Delmar Thomson Learning.

Departemen Kesehatan RI. (2005). Instrumen evaluasi penerapan standar asuhan keperawatan di rumah sakit (Cetakan ke lima). Jakarta: Direktorat Jenderal Pelayanan Medis Direktorat Pelayanan Keperawatan.

Domangue, E., \& Solmon, M. (2010). Motivational Responses to fitness testing by award status and gender. Res Q Exerc Sport, 81 (3), 310318 .

Indrastuti, Y., Hamid, A.Y.S., \& Mustikasari. (2010). Analisis hubungan perilaku caring dan motivasi dengan kinerja perawat pelaksana menerapkan prinsip etik keperawatan dalam asuhan keperawatan di RSUD Sragen (Tesis, magister tidak dipublikasikan). Program Pascasarjana FIKUI, Jakarta.

Jefferies, D., Johnson, M., Nicholls, D., \& Lad, S. (2012). A ward-based writing coach program to improve the quality of nursing documentation. Nurse Education Today, 32, 647-651. doi:10.1016/j.nedt.2011.08.017.

Joints Commission Internatioanl Accreditation (JCIA). (2011). Standards for hospitals (4th Ed.). Washington: Department of Publications Joint Commission Resources.

Kanfer, R., Chen, G., \& Pritchard, R. (2008). Workmotivation past, present, future. Florida: Society for Industrial dan Organisazational Psychology.

Khan, R.M., Ziauddin, Jam, F.A., \& Ramay, M. (2010). The impacts of organizational commitment on employee Job performance. European Journal of Social Sciences, 15 (3), 292-298.

Lu, L. (1999). Work Motivation, job stress, and employment well being. Journal of Applied Management Studies, 8 (1), 61-72. 
Martin, J.A. (2009). Interpersonal relationships, motivation, engagement, and achievement: Yields for theory, current issues, and educational practice. Review of Educational Research, 79 (1), 327-365. Doi: 10.3102/ 0034654308325583.

Marquis, B.L., \& Houston, C.J. (2006). Leadership roles and management, management function in nursing, theory and application. Philadelphia: Lippincott

McMurray, A.J, Scott, D.R., \& Pace, R.W. (2004). Relationship between organizational commitment and organizational climate to performance appraisal in manufacturing. Human Resource Development Journal, 15 (4), 473-488.

Meyer, J.P., Stanley, D.J., Herscovitch, L., \& Topolnytsky, L. (2001). Affective, continuance, and normative commitment to the organization: A meta analysis of antecedents, correlates, and consequences. Journal of Vocational Behavior, 61 (1), 20 52. Doi:10.1006/jvbe.2001.1842.

Owen, K. (2005). Documentation in nursing practice. Nursing Standard, 19, 48-49.

Persatuan Perawat Nasional Indonesia (PPNI). (2010). Standar profesi dan kode etik perawat Indonesia. Jakarta: Tim Penyusun PP PPNI.

Robbins, S.P. (2006). Organizational behavior (10th Ed.). New Jersey: Pearson education.
Rose, C.A., \& Kumar, R. (2009). The effect of organizational learning on organizational commitment, job satisfaction, and work performance. Journal of Applied Business research, 25 (6), 55-65.

Sonentag, S., \& Frese, M. (2001). Performance concepts and performance theory. Germany: John willey \& Sons.

Sulistyowati, D., Hariyati, T., \& Kuntarti. (2012), Analisis faktor-faktor yang mempengaruhi pencapaian target kinerja individu perawat pelaksana berdasarkan indeks kinerja individu di Gedung A Rumah sakit umum pusat nasional Dr. Cipto Mangunkusumo (Tesis, magister, tidak dipublikasikan). FIK UI, Jakarta.

Wahyudi, I., Irawaty, D., \& Mulyono, S. (2010) Hubungan persepsi perawat tentang profesi keperawatan, kemampuan dan motivasi kerja terhadap kinerja perawat pelaksana di RSU dr. Slamet Garut (Tesis magister, tidak dipublikasikan). FIK UI, Jakarta.

Wang, N., Hailey, D., \& Yu, P. (2011). Quality of nursing documentation and approaches to its evaluations a mixed-method systematic review. Journal of Advanced Nursing, 118. Doi: 10.1111/j.1365-2648.2011.05634.x

Yatnikasari, A., Sahar, J., \& Mustikasari. (2010). Hubungan program retensi dengan komitmen organisasi perawat pelaksana di RSAB Harapan Kita (Tesis magister, tidak dipublikasikan). FIK UI, Jakarta. 